\title{
Justice Sector Corruption: Will Indonesia Neutralize it?
}

\author{
Muhammad Yunus Idy and Andi Arfan Sahabuddin
}

\author{
Faculty of Law, Universitas Islam Makassar, Makassar, South Sulawesi, Indonesia
}

\begin{abstract}
Background: Though there are vigorous efforts made to fight corruption attitude and behavior, in Indonesia the judiciary sector is still characterized by the existence of rampant widespread corruption acts of crime. For instance, there are many judges who have been caught being bribed across the country. From the available data, of the 19 judges at the Corruption Eradication Commission, 53\% are those who make up the Corruption Adhoc judges, while the remaining 47\% are career judges.

Objective: This research was conducted to determine the corrupt behavior of judges in relation to carrying out their duties and authority in upholding justice.

Method: The study applied a normative juridical research method, which established that corruption behavior exhibited by judges in handling cases is still prone to criminal acts of corruption, is detrimental to justice seekers.

Conclusion: Thus, the judge's corrupt behavior as the foremost law enforcer can be prevented as early as possible, if justice is to be upheld at a national level.
\end{abstract}

Keywords: Behavior, Crime, Corruption, Judiciary, Judge and Law Enforcement.

\section{INTRODUCTION}

In Indonesia, the circle of justice, especially for judges, is to win the trust of society (Schütte, 2012). Judges often capture the attention of the public, especially with their decisions, which are sometimes controversial. The controversial decisions may contain legal considerations that tend to be unacceptable to the broader community (Hormati, 2017; Butt and Lindsey, 2010; Nardi 2008). According to Wasingatu (2002) judicial corruption occurs in almost all judiciary levels, from the district court to the supreme court (Syamsudin, 2011). Corruption in the judiciary's orientation also makes the stigma of public trust in the judiciary worse and damages the sense of justice of the community.

The former Chief Justice of the Constitutional Court, Akil Moktar, who was sentenced to life in prison and a member of the Constitutional Court Patrialis Akbar, sentenced to 8 years in prison, is an empirical fact of the most substantial corruption cases in the judiciary. The arrest of judges also makes sensational stories in the media (Hendrianto, 2016), the case of the arrest of six people, including two South Jakarta District Court judges, by the Corruption Eradication Commission $(\mathrm{KPK})$ in a night arrest operation on Tuesday, November $27^{\text {th }}$ into Wednesday 28,2018 . In an initial 24-hour process following the arrest, the KPK named two South Jakarta District Court judges, namely: Iswahyu Widodo and Irwanas suspects.

*Address correspondence to this author at the Faculty of Law, Universitas Islam Makassar, Makassar, South Sulawesi, Indonesia; Tel: (0411) 588167;

Fax: +62411588167; E-mail: yunusidym@gmail.com
The Corruption Eradication Commission also accused three other people, including East Jakarta Substitute Registrar, Muhammad Ramadhan, Advocate Arif Fitrawan, and Martin P. Silitonga. The KPK said Arif Fitrawan and Martin P. Silitonga gave bribes totaling around 650 million Rupiah to Iswahyu Widodo and Irwan, through Ramadan. The money was given to influence the interlocutory decision and the final verdict in the civil lawsuit to facilitate the cancellation of the PT CLM acquisition agreement by PT APMR in South Jakarta District Court in 2018 (Bernie, 2018; Kahfi 2018).

The Corruption Eradication Commission conducted an arresting operation (OTT) on unscrupulous judges and court clerks, that saw the apprehension of the Tangerang District Judge Wahyu Widya Nurfitri and the Registrar of Tuti Atika, for allegedly accepting bribes in the handling of civil cases to be tried in the Tangerang District Court. Both were suspected of taking bribes to the tune of 30 Million Rupiah provided by advocates Agus Wiratno and HM. Saipudin, related to handling cases in court. In the same year, the KPK again arrested ad hoc judge of corruption, Merry Purba and Substitute Registrar Helpandi and clerks all of Medan District Court, over allegations of receiving 130,000 Singapore dollars from corruption defendant Tamin Sukardi.

The money was given to influence the verdict in favor of Tamin. These corrupt practices have been dubbed the judicial mafia. It is an increasing trend that, up to now, seems unstoppable. Previously records indicate up to 27 judges and clerks that are entangled 
in corruption, this number is feared to increase if no effort is made to improve the guidance and supervision of the Judicial system. Based on data from the Judicial Monitoring Coalition, at least 27 Judges and registrars were caught by the KPK on corruption cases. Some of them even have individual judges who handle criminal acts of corruption.

Adi Andojo Soetjipto has ever exposed the collusion case in the Supreme Court in the Gandhi Memorial School case (Laoly, 1996). More to that are the allegations of bribery of two current justices and a retired Chief Justice who is suspected of having received bribes worth tens of millions of Rupiah based on reports received from the reporting witnesses as victims (Suparman, 2006). Once revealed, the phenomenon of judicial corruption committed by judges in courts through various print and electronic media (Sahlan, 2016). Promotion of judges and also handling cases that were considered "wet" such as corruption, many elements contained judicial corruption (Sahlan, 2016). Likewise, in handling other cases in court, many irregularities indicate judicial corruption (Butt and Lindsey, 2010). From various legal regulations that normatively regulate the entire judicial process, they are ultimately powerless to advocate for judicial corruption. According to the International Commission of law, judicial corruption is the highest crime because it destroys part of the pillars of a democratic government (Hormati, 2006). The process of handling cases by a judge in a court is not only a juridical technical matter and procedural application of regulations. Still, it involves the orientation of the values held by the judge.

In the process of dropping a decision, a method of thinking, weighing, and dialogue of judges with values residing in the judge's rational nature. Very precisely what was said by Ronald Beiner as cited by Viapiana (2018) the judge's decision was "... mental activity that is not bound to rules ..." (Syamsudin, 2011). The judge will sort out and choose what values will be realized. The embodiment and choice of these values in practice are primarily determined by factors which include: the level of interest, knowledge, necessities of life, environment and habits, and the personal character of the judge. These factors will determine the direction of the judge in deciding the case (Syamsudin, 2011). Based on the thoughts outlined above, in writing this article, the main problem to be discussed is 'what is the pattern of corrupt behavior in the judiciary in Indonesia?'

\section{RESEARCH METHOD}

Following the problems examined by the author in this article, the method used is the library research method. A literature study or type of library research can be interpreted as a series of activities relating to library data collection, reading and recording, and processing research materials. The research material in this article is in the form of secondary sources of data explaining the phenomenon of corrupt behavior in the legal environment in Indonesia. Various sources of literature support them in the way of research results and reports on corruption from multiple components or institutions concerned with eradicating corruption and numerous theoretical study references from numerous journals and books. The explained library research limits its activities to the collection of books without the need for research in the field.

\section{FINDINGS AND DISCUSSION}

\section{Corruption Behavior of Judges in Judicial Institutions}

Corruption behavior is defined as corruption when deviating from the rules to increase personal interest and matters related to personal economics or improving status (Anderson and Tverdova, 2003). Othman, Shafie, and Hamid (2014) define corruption as the relationship of two elements; particular interest in deviant behavior and personal fortune. There are many forms and deviations or abnormal behavior in the scope of corruption. In-Law Number 31 of 1999, as amended by Law Number 20 of 2001 concerning the eradication of corruption, there are at least 8 (eight) typologies of corruption offenses, namely: a. Offenses that can harm the country's finances or the country's economy; b. The bribery offenses (active or passive); c. Embezzlement offenses; d. Extortion; e. Counterfeiting offenses; $f$. Offenses related to tendering and procurement; g. Offenses related to gratification; $h$. Offenses of obstruction and prevention of handling of corruption cases (Bambang, 2014). Concerning the forms of corruption that often occur in judicial institutions, we focus on the bribery offense typology (active or passive). Behaviors such as bribery--the use of gifts to distort one's judgment in a specific position that is trusted; nepotism-- the gift of protection or guarantee of a written relationship rather than the quality of the individual; and misuse-- the illegal use of public resources for purposes that are related to personal interests (Ramadhan, 2017). Bribery is an act of giving money, goods or other forms of retaliation 
from the bribe giver to the recipient of a bribe that is done to change the recipient's attitude towards the interests/interests of the giver, even if the position is contrary to the recipient (Gneezy et al., 2019; Xu et al., 2019; Köbis et al., 217). The issue of judicial corruption is related to the phenomenon of bribery to law enforcement officials (police, prosecutors, clerks, and judges) by certain parties, extortion to give bribes to law enforcement officials in handling legal cases. Besides, outside parties of the judiciary also become part of corrupt practices such as case brokers. Because corruption is widespread in the courts, the public calls it the judicial mafia. The legal mafia has more connotation on the corrupt practices between judges, lawyers, and prosecutors, as well as other parties in the judiciary, namely referring to a conspiracy to win one particular party (Butt, 2017; Butt and Lindsey, 2010; Idami, 2018; Iqbal et al., 2019).

Nevertheless, judicial corruption is not only a problem of the Supreme Court. Some lawyers and business people are also involved in bribery cases. One of the senior lawyers, Otto Cornelous Kaligis (OCK), was also convicted as a perpetrator in a bribery case involving judges and court clerks of the PTUN Medan in mid-2016. OCK was engaged in providing bribes handling matters of the North Sumatra Provincial Government's social assistance fund, Gatot Pujo Nugroho. Bribery was obtained from Gatot's wife so that her husband would not be "pulled" into the case. OCK was found guilty of carrying out article 6 paragraph (1) 'an" of the PTPK law, Article 55 paragraph (1) of the 1st KUHP, Article 65 paragraph (1) of the KUHP12. Based on the results of the Global Corruption Barometer survey conducted on respondents from all over the world, the judiciary ranks third after the police as the most corrupt institution (Holmes, 2018; Gutierrez-Garcia and Rodríguez, 2016). The mode used varies, but the most commonly found is a case of bribery. Lukito (2016) noted that the police and community justice were the two institutions that received the most bribes, with an estimated $24 \%$ of the judicial institutions claiming to have given bribes (Buttle et al., 2016; Quah, 2019). Even reports of bribery for legal institutions in Indonesia have increased by more than $20 \%$ (Lukito, 2016). The granting of bribes turns out not only to be done on the substance of the case, but also on matters outside the content of the case. Related to the element of the case, for example, corruption mode has even been seen since the beginning. The Legal Mafia Eradication Task Force states that legal mafia has occurred since the beginning of the phase with the most frequently encountered mode, namely the existence of unofficial requests to offer the use of advocates who have relations with the judges (Derek, 2017).

\section{Mode of Judicial Corruption}

The former chief justice of the Supreme Court of the United States Earl Warren (1953-1969) once said, "In civilized life, law floats in a sea of ethics" (Fox, 2002; Robart, 2017). Without ethics, the law is only a wad of books and documents containing statutes, without a sense of justice (Sourya and Whitehead, 2019; Braswell et al., 2017). The two norms, ethics and law, are often separated. However, the truth is that two sides of a coin give each other soul and value to establish a society of noble civilization (Kleinberger, 1988). The condition of the judge's behavior in the practice of handling a case in court is inseparable from, and influenced by, the value system adopted. Judges will always struggle and have a dialogue with a value system that resides in the psychiatric realm and mentality of the judge (Amarini, 2020; Viapiana, 2018; Brafford and Rebele, 2018). The judge will choose what values are prioritized and which are prioritized for a case presented to him.14 The judges always struggle and dialogue with values when handling a case. If the judge deviates from the values held, he may feel guilty, guilty, not sleeping well, and have other haunting feelings. This applies to judges who have moral sensitivity and conscience. But if the judge does not have moral sensitivity and conscience, then what is followed is impulse and interests that benefits individuals.

Judicial Monitoring Coalition (KPP) stated that the modes of corruption in the world of justice had not been much reduced (Ramli and Arifin, 2020; Said, 2018). This indicates that there is still a darkroom used by the judicial mafia to hijack the court's decision for their interests. One member of the coalition, Bivitri Susanti from the Jentera School of Law, said that reforms in the judicial sector had been carried out since 1999. However, the reality did not positively impact eradicating the rise of the legal mafia in the judiciary. "The practice of judicial mafia takes place on the ground. There are several patterns or modes that they use to regulate their nets," Bivitri said when giving a press statement at the YLBHI office, Central Jakarta. Bivitri explained that five modes often occur within the scope of the court. In the pre-trial stage, Case brokers build good relations with judges or court employees by providing gifts or facilities. The goal is to create a debt of gratitude when litigating. At the stage of registering 
cases, illegal payments are often found outside the provisions of case registration and offer the use of certain advocate services. Typically, said Bivitri, the person will claim to speed up or slow down the investigation of the case. Another standard mode, case brokers often ask certain parties to arrange a panel of judges at the time of determination of the panel of judges. Whereas in the trial process, an attempt is usually made to fabricate the trial by arranging witnesses, supplying evidence to regulating court decisions. In the last mode, he continued, namely illegal fees, requested by some aspects to accelerate or slow down the decision. "All of those modes are still plural. Deviations occur when the decision is mutated. These are ways to get money," said Bivitri. Bivitri alluded to the Ombudsman investigation, which found brokering practices in several courts. The brokers promised to help justice seekers at a specific price. Departing from this reality, Bivitri urged the Supreme Court head to make strategic steps to address the problems of corruption that are rife in judicial institutions. This decisive step was carried out by forming a special team under the Supreme Court supervisory body and collaborating with the KPK and the Judicial Commission in mapping the justice mafia network and formulating a surveillance system. The Judicial Monitoring Coalition consisting of ICW, YLBHI, PSHK, and MaPPI once made a study of how the modus operandi of the judicial mafia works. In the study, there are at least five modes that often occur within the court's scope, namely: First, pre-trial. In this context, case brokers build good relations with judges/court employees by giving gifts or facilities that aim to create a debt of gratitude when litigating. Second, the case registration, namely the existence of illegal fees outside the provisions when registering a case, offers the use of certain advocate services to speed up or slow down the case investigation. Third, the determination of the panel of judges. In this context, case brokers ask certain parties to arrange judges. Fourth, the trial process, such as trial engineering, witnesses, or evidence tampering. Fifth, illegal payments to speed up or slow down decisions.

The Indonesian Ombudsman found several problems in the practice of justice in the country. One very worrying issue is the practice of brokering the winning of cases in the judiciary. It was proven in the

\section{Table 1: Illustration of Modes of Corruption}

Request for Service Fees: The registration department in the court will ask for money when a power of attorney is registered with the defendant's lawyer. If not, the registration process will be delayed. In the trial process, the Panel of Judges plays a central role because it determines what decisions will be handed down. This role's size makes the potential for corruption, namely corruption, in assessing the Panel of Judges who will examine the case.

Determination of the Panel of Judges: There is an assumption that for significant cases, it will be directly handled by the Chairperson of the PN. In practice, in certain PN-PN, there is a Panel of Judges who are the preferred choice for handling cases. How to choose the Panel of Judges for lawyers who do not have a good enough relationship is through a clerk's services.

Decision Negotiation:

Entrance: The Public Prosecutor, Registrar, or Judge is directly inclined to judge $2 / 3$ of the demands

Sample case: Dicky Iskandar Dinata. 750 million Rupiah for a 10-year sentence

Marathon Trial: In one day, more than one trial agenda was held. Such a way of handling cases leaves a lot to be answered.

Illegal levies for certificates of freedom Case / Certificate of Never Law (SKBP): SKBP is a document that is needed by the company or individual to show that they have never been involved in a case. The need for this SKBP is quite significant, especially for companies that will conduct Initial Public Offering, restructuring, credit to banks, bond issuances, merger acquisitions, etc.

Appeal and Cassation: Illegal levies that are not regulated. Not informed of completeness of the file or sent late.

Decision: There is no clarity on whether the cost is included in the cost of the case or outside the cost of the case.

Power of attorney: 50,000 Rupiah per power of attorney, is charged to the parties. Even though it is in the composition of costs.

Summon for Witnesses: civil cases are included in the component, and for criminal cases, there is no charge.

Summon of the Parties. Charged to the Parties, whereas in the composition of civil litigation costs included in the component.

Relationship Notifications: Sent to the RW or Lurah Chairperson so that the information does not reach the parties.

Notification and Granting Access to First-level decisions, Appeal, Appeal, and Review: The court clerk does not decide to obtain the resolution and quires additional costs outside the cost of the case.

Session Schedule: There are indications that for the hearing to be held more quickly, there needs additional costs.

Oath money and oath swearing: Oaths have asked for fees to finish swearing witnesses to the parties.

Legal Aid Post: Extortion of the parties by government legal services advocates as an extension of the judge or prosecutor.

Remaining deposit Case: Management of the remaining down payment in the case.

Savings Credit by the Registrar: As a form of support from the parties to the court clerk to provide information about the case being handled.

Local Inspection (PS): Judge Asks Dependents' Pocket Money from the Parties

Source: Wasingatu (2002). 
Ombudsman's investigation of the Republic of Indonesia, and the administrative staff asked for bidders for justice seekers to reach tens of millions of Rupiah. The Chairman of the Indonesian Ombudsman, Ninik Rahayu, said the findings were obtained from an investigation on its initiative in efforts to improve and improve the quality of public services and the administration of justice in Indonesia. Although the District Court has a standard mechanism in terms of providing services to the community, in practice, it is still often found violations of these mechanisms, even many of them are forms of corruption in public services, namely illegal levies. Here are some kinds of fraud in handling cases in court based on the Focus Group Discussion results and the literature in a book entitled "Exposing Judicial Mafia" in 2002 written by Wasingatu. Corruption modes are summarised as follow:

This investigation focuses on case registration services, trial schedules, provision of copies, and excerpts of decisions. The focus of the supervision is on the trend of public complaints to the Republic of Indonesia's Ombudsman pockets, increasing in number over the years. "Brokering practices became the most findings from this investigation, and the amount of money requested for the promise of winning the case was very much up to tens of millions of rupiah," Ninik said in a press release received by Kompas.com (Aerlang, Reginasari and Annisa, 2016). Ninik said the various maladministration findings were obtained by the team through the mystery shopper or pretending to be a service user to many district courts. (read: RI Ombudsman Reveals Number of Complaints to the Court, This is the Comment of the Supreme Court) The results obtained are findings of procedural irregularities in case registration, delays in carrying out trial schedules, deviations in procedures for submitting copies of decisions and excerpts of choice, brokering practices, and non-fulfillment of service standards in court. Another Indonesian Ombudsman Chairwoman, Adrianus added that 17 of the several public services in court, the power of attorney registration service, and obtaining a copy of the decision are two services that are very significant opportunities for extortion. Methods often used by these elements in acting are: set costs outside the provisions and are not accompanied by proof of payment, do not provide change, in return or fatigue, and extend service if no tip/money is requested.

\section{CONCLUSION}

From the description above, it can be concluded that the judge's corrupt behavior in handling a case in court is inseparable from and influenced by the value system adopted. The value system that resides in the psychiatric realm or mentality of judges greatly determines judges' behavior in handling cases. The acts of corruption that develop within the judiciary are known to most people. Citizens also know the various types of corrupt activities carried out such as in the pretrial stage, stage a, case registration, stages, determination of judges, stages of the trial process, such as the fabrication of hearings, arranging witnesses or evidence to the court's decision, the decision of the minuting stage, namely extortion to speed up or slow down the minuting of choices and the practice of bribery and brokering to win cases injustice.

\section{REFERENCES}

Aerlang, M., Reginasari, A., \& Annisa, V. (2016). Pakar Rupia (Apa Kerja Keras Koruptor Indonesia?): Membangun Sanksi Psikososial Bagi Terpidana Kasus Korupsi. Integritas 2(1).

Amarini, I. (2020). Implementation of Verdict Based on Pancasila Values in Indonesia. In International Conference on Law, Economics, and Health (ICLEH 2020) (pp. 697-700). Atlantis Press. https://doi.org/10.2991/aebmr.k.200513.132

Anderson, C. J., \& Tverdova, Y. V. (2003). Corruption, politica allegiances, and attitudes toward government in contemporary democracies. American Journal of Political Science, 47(1), 91-109. https://doi.org/10.1111/1540-5907.00007

Bambang W. (2014). Optimalisasi Pembrantasan Korupsi Di Indonesia, Jurnal Yuridis, 1(2), 169 - 182.

Brafford, A., \& Rebele, R. W. (2018). Judges' Well-Being and the Importance of Meaningful Work. Ct. Rev., 54, 60.

Braswell, M. C., McCarthy, B. R., \& McCarthy, B. J. (2017). Justice, crime, and ethics. Taylor \& Francis. https://doi.org/10.4324/9781315455853

Butt, S. (2017). Corruption and law in Indonesia. Routledge. https://doi.org/10.4324/9780203584729

Butt, S., \& Lindsey, T. (2010). Judicial mafia: The courts and state illegality in Indonesia. In The state and illegality in Indonesia (pp. 189-213). Brill.

https://doi.org/10.1163/9789004253681_011

Buttle, J. W., Graham Davies, S., \& Meliala, A. E. (2016). A cultural constraints theory of police corruption: Understanding the persistence of police corruption in contemporary Indonesia. Australian \& New Zealand Journal of Criminology, 49(3), 437-454. https://doi.org/10.1177/0004865815573875

Derek, B. (2017). Pelaku Tindak Pidana Korupsi sebagai Justice Collaborator menurut Hukum Pidana di Indonesia. Lex et Societatis, 5(5)

Fox, M. L. (2002). To tell or not to tell: Legal ethics and disclosure after Enron. Colum. Bus. L. Rev., 867

Gneezy, U., Saccardo, S., \& Van Veldhuizen, R. (2019). Bribery: Behavioral drivers of distorted decisions. Journal of the European Economic Association, 17(3), 917-946. https://doi.org/10.1093/jeea/jvy043

Gutierrez-Garcia, J. O., \& Rodríguez, L. F. (2016). Social determinants of police corruption: toward public policies for the prevention of police corruption. Policy Studies, 37(3), 216-235. https://doi.org/10.1080/01442872.2016.1144735 
Hendrianto, S. (2016). The Puzzle of Judicial Communication in Indonesia: The Media, The Court and the Chief Justice. Justice and Journalists: The Global Perspective (Cambridge University Press, 2016 Forthcoming).

Holmes, L. (2018). Police Corruption. In Oxford Research Encyclopedia of Criminology and Criminal Justice. https://doi.org/10.1093/acrefore/9780190264079.013.633

Hormati, D. S. (2017). Kajian Yuridis Tentang Peran Komisi Yudisial Dalam Penegakkan Kode Etik Mengenai Perilaku Hakim. Lex Privatum, 5(8).

Idami, Z. (2018). Factors Affecting Harmony among Law Enforcement Agencies in Indonesia. Padjadjaran Journal of Law, 5(1), 164-181. https://doi.org/10.22304/pjih.v5n1.a9

Iqbal, M. I., Susanto, S., \& Sutoro, M. (2019). Functionalization of ECourt System in Eradicating Judicial Corruption at The Level of Administrative Management. Jurnal Dinamika Hukum, 19(2), 370-388.

Kahfi, K. (2018 November 28). KPK names two judges bribery suspects, pushes for judicial reform. The Jakarta Post. Retrieved from https://www.thejakartapost.com/news/2018/ 11/29/kpk-names-two-judges-bribery-suspects-pushes-forjudicial-reform.html

Kleinberger, D. S. (1988). Wanted: An Ethos of Personal Responsibility--Why Codes of Ethics and Schools of Law Do not Make for Ethical Lawyers. Conn. L. Rev., 21, 365.

Köbis, N. C., van Prooijen, J. W., Righetti, F., \& Van Lange, P. A. (2017). The road to bribery and corruption: Slippery slope or steep cliff?. Psychological science, 28(3), 297-306. https://doi.org/10.1177/0956797616682026

Laoly, Y. H. (1996). Kolusi: Fenomena atau Penyakit Kronis, dalam Aldentua Siringoringo dan Tumpal Sihite. In Menyingkap Kabut Peradilan Kita: Menyoal Kolusi di Mahkamah Agung (Jakarta: Pustaka Forum Adil Sejahtera, 1996).

Lukito, A. S. (2016). Building anti-corruption compliance through national integrity system in Indonesia. Journal of Financial Crime, 23(4), 932-947. https://doi.org/10.1108/JFC-09-2015-0054

Bernie, M. (2018, Novemer 29). OTT Hakim PN Jaksel: Antara Mafia Peradilan \& Pengawasan yang Lemah. tirto.id

Nardi Jr, D. J. (2008). Do Indonesian Judges Need Scientific Credibility-Indonesia v. PT Newmont Minahasa Raya and the Use of Scientific Evidence in Indonesian Courts. Geo. Int'I Envtl. L. Rev., 21, 113.

Othman, Z., Shafie, R., \& Abdul Hamid, F. Z. (2014). CorruptionWhy do they do it?. Procedia-Social and Behavioral Sciences, 164, 248-257. https://doi.org/10.1016/j.sbspro.2014.11.074

Quah, J. S. (2019). Combating police corruption in Indonesia: cleansing the buaya (crocodile). Asian Education and Development Studies. https://doi.org/10.1108/AEDS-04-2018-0088
Ramadhan, C. R. (2017). Pola dan Prevalensi Korupsi Pengadilan di DKI Jakarta, Fakultas Hukum UI berekrja sama dengan Masyarakat Pemantau Peradilan Indonesia FHUI bersama Yayasan TIFA.

Ramli, I., \& Arifin, A. Z. (2020). Taxation System, Tax Sanctions, Justice, Discrimination, and Probability of Cheat Detect Impact on Taxpayer Perception Regarding Tax Evasion Ethics (Study at Primary KPP in Yogyakarta). In Tarumanagara International Conference on the Applications of Social Sciences and Humanities (TICASH 2019) (pp. 528533). Atlantis Press. https://doi.org/10.2991/assehr.k.200515.089

Robart, J. L. (2017). Commencement Remarks-Reflections on Being a Lawyer. Or. L. Rev., 96, 11.

Sahlan, M. (2016). Kewenangan Peradilan Tipikor Pasca Berlakunya Undang-Undang Administrasi Pemerintahan. Arena Hukum, 9(2), 166-189. https://doi.org/10.21776/ub.arenahukum.2016.00902.2

Said, L. (2018). Implementation of tax amnesty and its impact on Indonesia economics. Reports on Economics and Finance, 4(1), 45-56.

https://doi.org/10.12988/ref.2018.815

Schütte, S. A. (2012). Against the odds: Anti-corruption reform in Indonesia. Public Administration and Development, 32(1) 38-48. https://doi.org/10.1002/pad.623

Souryal, S. S., \& Whitehead, J. T. (2019). Ethics in criminal justice: In search of the truth. Routledge. https://doi.org/10.4324/9780429400278

Suparman, E. (2006). Asal Usul serta Landasan Pengembangan IImu Hukum Indonesia. In A., Gunawan \& M., Ramadhan: Menggagas Hukum Progressif Indonesia, Penyunting. Yogyakarta: Pustaka Pelajar.

Syamsudin, M. (2011). Rekonstruksi perilaku Etik Hakim dalam Menangani Perkara Berbasis Hukum Progresif. Jurnal Hukum lus Quia lustum, 18, 127-145. https://doi.org/10.20884/1.jdh.2011.11.1.11

Viapiana, F. (2018). Pressure on Judges: How the Budgeting System Can Impact on Judge's Autonomy. Laws, 7(4), 38. https://doi.org/10.3390/laws7040038

Wasingatu, Z. (2002). Menyingkap tabir mafia peradilan. Indonesia Corruption Watch (ICW).

Xu, D., Zhou, K. Z., \& Du, F. (2019). Deviant versus aspirational risk taking: The effects of performance feedback on bribery expenditure and R\&D intensity. Academy of Management Journal, 62(4), 1226-1251. https://doi.org/10.5465/amj.2016.0749

Received on 04-12-2020

Accepted on 05-01-2021

Published on 18-01-2021

\section{DOI: https://doi.org/10.6000/1929-4409.2021.10.06}

(C) 2021 Idy and Sahabuddin; Licensee Lifescience Global.

This is an open access article licensed under the terms of the Creative Commons Attribution Non-Commercial License (http://creativecommons.org/licenses/by-nc/3.0/) which permits unrestricted, non-commercial use, distribution and reproduction in any medium, provided the work is properly cited. 